\title{
Skill Gap Analysis in the Ship Breaking Industry of Pakistan
}

\author{
Sayed Asghar Shah, Hadi Hussain, Mujahid Hussain \\ GIZ Islamabad Pakistan and PEDA International, Islamabad, Pakistan \\ Email: Bangash0012@gmail.com, asgharpcr@gmail.com
}

How to cite this paper: Shah, S.A., Hussain, H. and Hussain, M. (2017) Skill Gap Analysis in the Ship Breaking Industry of Pakistan. American Journal of Industrial and Business Management, 7, 1244-1254. https://doi.org/10.4236/ajibm.2017.711088

Received: October 18, 2017

Accepted: November 27, 2017

Published: November 30, 2017

Copyright (c) 2017 by authors and Scientific Research Publishing Inc. This work is licensed under the Creative Commons Attribution International License (CC BY 4.0).

http://creativecommons.org/licenses/by/4.0/ (c) (i) Open Access

\begin{abstract}
Geographically Pakistan gains much importance in the sea linkages as it intersects the three main sea lines of communication (SLOCs). After the project China Pakistan Economic Corridor (CPEC), there we see improvement in infrastructure of every sector which is linked with it. But the Ship breaking sector located at Gaddani, Pakistan was still ignored. And the main focus of our study is on the safety measures, education, health, and demands of TEVT graduates in this sector. Data is collect through survey in 2016. At start the ship breaking sector was on peak and become the No. 1 sector around the globe but unfortunately this sector in performance getting down and down with time. There are three main reasons, first, the high tax rate was imposed, second, there was no proper safety measures as we see deaths and injuries incidents are taken place, no proper medical facilities are available and third there was no proper training and education for the workforce which are engaged in this sector. All the needs of this sector to make it Green are addressed in this study properly. If all the measures which we addressed for the improvement of this sector is handled properly than this sector will contribute much more to GDP in different ways as this sector in terms of employment, and will also produce much more steel which not only fill the demand of steel domestically but also we will export it to different countries.
\end{abstract}

\section{Keywords}

Skill Gap Analysis, Ship Breaking Sector, Pakistan

\section{Global Outlook}

This industry is much wider as 1000 ships are breaking down per year around the globe. And the dismantling includes all kinds of ships i.e. passenger ships, bulkers, container ships etc. to recover steel which is used in many other things [1]. The countries which work in this industry are US, Canada, Denmark, Tur- 
key, Pakistan, Belgium, Denmark, India, Mexico, Bangladesh, China, and UK. But due to low labor cost and less restriction on buyer and seller South Asia is the main center of global Industry. The ship dismantling sector is ignored too much that's the reason of un-availability of data so according to the study of Capt. Khalil U Khan (2014) he mentioned the percentages of shipbreaking around the globe [2]. As 68\% ship were dismantled in South Asia, 17\% in china, $12 \%$ in Turkey, $2.2 \%$ in European Union and $0.8 \%$ in rest of the Globe. The Reason of the high rate of ship dismantling in developing countries was that because in South Asian countries the ship is dismantled without taking care of pollution, no barriers for buyer and seller, no workforce life security, that's why cheap labor and that's the main reason of attraction. As we see that ship-breaking industry is on peak in South Asian countries. So in the near future the environment will be hazard more and more, so government should have to take a proper step to get rid of this future hazard. For this the ship breaking yard should be locked in the coastal areas for easy wastage of hazardous waste scraped from ships. Proper medical facilities for work force and there be proper work training through TEVTA.

The Figure 1 clearly shows the percentages of those countries which are involved in ship breaking industry. As most of the world ships are dismantled in India due to cheap labor, than the second country after India which dismantles ships is Bangladesh and then china, after China the fourth big country which dismantles ships is Pakistan, than Turkey, European Union, and then the remaining countries of the world work in this sector.

\section{South Asia Outlook}

As we say earlier that South Asia is the focus point with respect to this sectors due to bundle of reasons. Like due to cheap labor, less restrictions on buyer and sellers, no environmental safety issues, no medical insurance of work force and no proper disposal of wastages. So these are the reasons of low cost of ship breaking but this is the natural phenomena that where are ships made they are

Ship Breaking Industries around the Globe: 2012

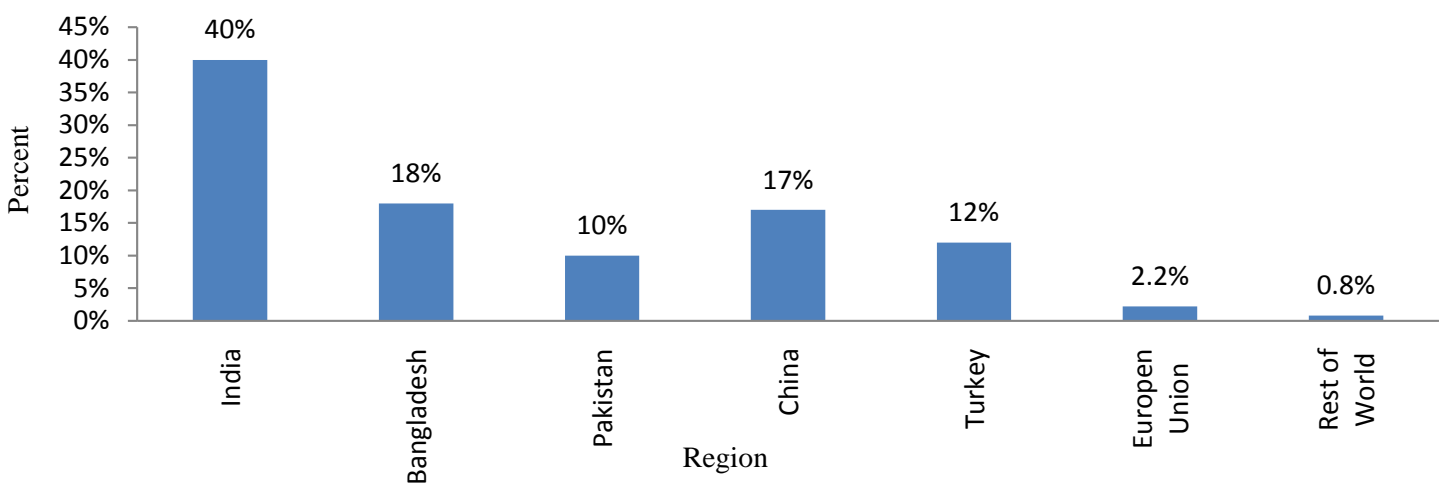

Figure 1. Ship breaking industry around the Globe (2012). 
disposed on the same place but due to many restrictions and high labor cost they are attracted to South Asian countries. In 2012 as 40\% of ships are scrapped in India, Bangladesh dismantles $18 \%$ and Pakistan dismantles $10 \%$ of the Global activity [2]. Worker in this region is hired on daily basis and most of them are illiterate and don't have any skills how to work safely. Since the past few decades there are many International and National criticism on this sector in South Asia. But only India worked on the betterment of this sector as they made hospital near to yard and made rules for worker that only ISO30 certified worker can be able to work.

The ship breaking industry on international or on developed country standard is hazard free that's why the cost of dismantling is too high and there are many barriers for the buyer and that's the big reasons of attraction of customers towards south Asian countries because there they got handsome money [3].

The Figure 2 shows the ship breaking industry performance in South Asia. And according to the world prospective the South Asia captures $68 \%$ of world ship breaking market. And the percentage shown in pie is of $68 \%$. So India captures 59\% in South Asian market and $40 \%$ in world market. Bangladesh captures $26 \%$ in South Asian market and 18\% in world market and Pakistan captures 15\% in South Asian market and 10\% in world market [2].

\section{Pakistan Outlook}

According to the study of Prof. Captain Khalil U Khan (2014) the Ship Breaking in Pakistan is started in 1947 at Gadani. Gadani is a village of Lasbela district located in the southern part of Baluchistan along the Arabian Sea, Pakistan [2]. This industry is one of the most hazardous and this industry was much active after the independence. The ship breaking industry is mainly link with the demand of steel in domestic and international market. Gadani is now the world third largest ship breaking yard in term of capacity and in term of efficacy it is the fourth ship breaking yard. Gadani Ship breaking yard contain 128 ship breaking lots and the annual capacity of ship breaking is up to 125 ships of all sizes [3]. This Industry was active in the era of 1970-1980 [3], and become the world more efficient industry. But its performance become very low when high

Ship Breaking Industries in South Asia: 2012

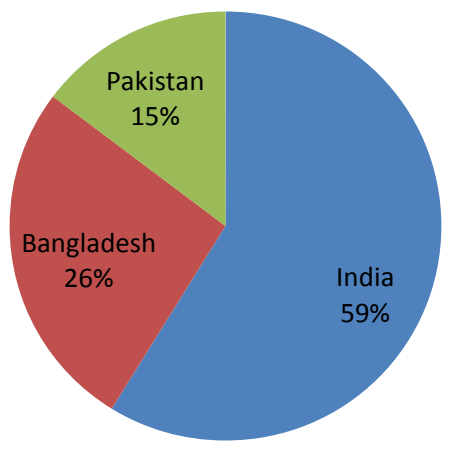

Figure 2. Ship Breaking Industries in South Asia (2012). 
tax imposed in 1997 and that's why the competitors grow more and more and Pakistan become the least efficient [2]. And revival of this industry has been seen in 2012. According to the Dewan Rizwan Farooqi Chairman of PSBC this sector pays 5 billion annual taxes to the Pakistan government, out of which $30 \%$ has been given to Provincial government [4]. In the economic prospective this industry reduces imports by providing steel to many of the steel industries [4]. Which ultimately contributed in GDP, as this industry is a high contributor to GDP so government have to think about its revive to make it "Green Ship breaking" industry and match it with the international standards for country betterment. The performance of this industry goes up and down due to political instability. The main reason due to which this industry is get slow in competition is high imports duties after 1980. 1997 high import duties were imposed on this sector and in 2002 its performance becomes a little good due to some relaxation in imports duties [2]. In 2009-2010 records of 107 ships were broken at Gadani and in 2008-2009 86 ships were broken into scraps [5]. And most of the scraps are sold locally. The very interesting fact is that a ship with 5000 LDT is broken in 30 - 45 days at Gadani, whereas the same weight ship was broken in almost 6 months in India [2].

The main motivation of the study is the gradual decrease in efficiency and the incidents which a taking place day by day. And the ignorance of such an important sectors both by government and private business. Our interest is to figure out the reasons of why there is decrease in its efficiency and incidents that occur. If we take a look from 1980 to 2016 instead of development this sector is going down and down through ages. As in 1980 Gaddani was the world largest ship breaking yard as it employee's more than 30000 labors [3]. But as it came in competition with Alang, India and Bangladesh its output reduces almost 1/5 if we compare with the output of 1980 [5]. The main reason of the inefficiency is high imports duties which were imposed in 1997. The sector contributes much to GDP and pays a high volume of tax as I mentioned earlier [2]. As Government show a little reliability in reduction of tax on scrap and as a result they now employ 6000 workers. This industry also fills the unemployment gap on Baluchistan level as $20 \%-25 \%$ of the labor force is engaged in this sector [6].

Due to less interest of government and private business incidents are taking place due to lack of protective measures and less skill work force. As shipbreaking is hazardous sector so there is need of much skilled work force, labor security and other medical facilities.

The Figure 3 tells that in the era of 1980's this industry was on its peak as it employees almost 30000 of labor and in the era of 1990's the high imports duty of $45 \%$ was imposed on this sector as we clearly see the black line in the graph and due to this act the employment decrease from 30000 to 5000 and later in the era of 2000 the government reduces tax on scraps so the employment level increases. In the study of Capt. Khalil U khan (2014) he mention that $45 \%$ import duty was imposed in the early 90's and the black line in the graph shows that 


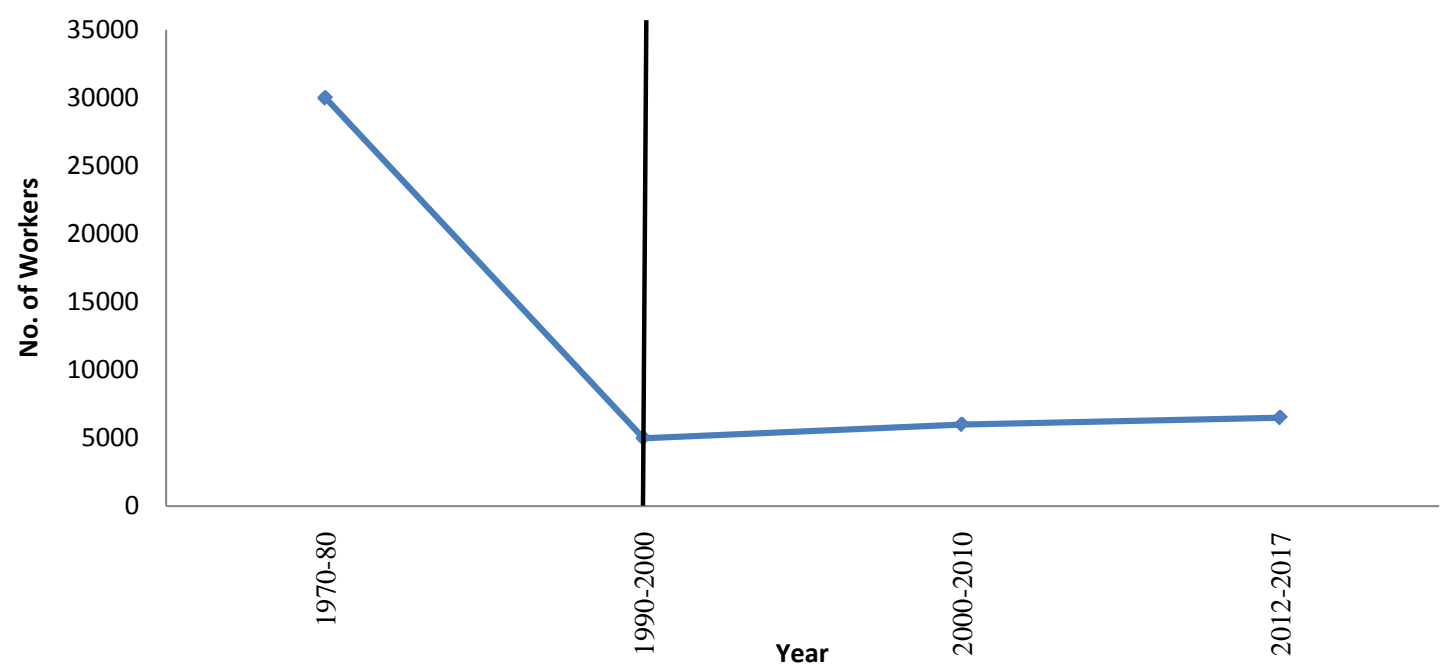

Figure 3. Employment in Ship Breaking Industry of Pakistan (2017).

imposed import duty due to which there comes the huge down fall in the production [2]. Than in 2001 the government reduces import duty $10 \%$ to $15 \%$ and we see that the production changes slightly. ${ }^{1}$

\section{Ships Dismantled in Pakistan}

The Table 1 shows the number of the Vessels which are beached at Gadani for dismantling and the data is collected from the Seven Ocean Service of Pakistan. And this source is not so valid because it shows only the number of vessels beached, not the number of small ships which are dismantled at Gadani [7].

\subsection{Protective Measures}

\section{a) Personal Protective Measures:}

The personal protective measure is one of the basic needs of this industry, which is totally ignored in Pakistan. Some of these basic personal protective equipment's which are barely used at Gaddani are helmets, climbing gear, mask for respiratory protection, proper shoes, and most important thing googles used in torch-cutting are barely used. These are basic needs for protections are not given to worker in Gaddani ship breaking yard. Things which are given a rejust hat, shoes, and simple googles and due to high temperature and humidity workers couldn't use them. And nobody is properly asked that why they are not using them simply no proper rules and safety measures.

b) Environment Protective Measures: Ship breaking industry is hazardous to both regarding safety of worker and safety of environments also. As ship are broken into pieces so there is no proper storage for scraps. And there is no such disposal of wastes which is the main cause of pollution. These ships contain more toxic materials like asbestos, heavy metals, polychlorinated biphenyl, 
Table 1. Vessels Beached at Gadani.

\begin{tabular}{cccccccccc}
\hline Years & 2009 & 2010 & 2011 & 2012 & 2013 & 2014 & 2015 & 2016 & 2017 \\
\hline Vessels Beached for dismantling & 36 & 42 & 35 & 52 & 35 & 53 & 22 & 43 & 38 \\
\hline
\end{tabular}

polyromantic hydrocarbons, and organotin like tributyltin. There is no proper procedure to dispose off all these toxic materials safely. Basically these are the main toxic materials which are hazardous for both workers life and for environment. The scraps which are cut down from the ship are placed in any open area in the yard and there is no proper place to keep them safe.

\section{c) Incidents:}

Basic reasons of the injuries which workers are facing day by day is just only because of safety measures, which includes not only the use of protective instruments but it also a signal to educated the work force through proper technical and vocational training. Different cases of injuries can in front like cuts, burns and many more. According to different media, Newspaper and Wikipedia annually $35 \%$ are cuts injuries and $31 \%$ are burn injuries which are taking place [6]. Other reasons of all these injuries are daily wages workers as mostly workers are on daily wages system and they are not proper trained and not even trained for long term, shocking thing that the foreman of workers are not even trained. Numbers of worked dead in this ship breaking yard due to ill safety measures as 12 men dead in 2012, 4 were dead in 2013, on $1^{\text {st }}$ November 2016, 26 were dead and 59 were burned due to gas exposition [8]. Recently 5 were dead and 2 are missing in the incident of $9^{\text {th }}$ January 2017 [9] [10]. And most of these deaths are because of explosion, height fallings, crushed under steel plates, and mostly by suffocation. These are the recorded deaths; injuries and much causality are not recorded. The death toll from 2012 to 2017 is clearly shown in Figure 4.

\subsection{Survey Based Analysis on Ship Breaking Industry}

The GIZ Pakistan conducted a survey regarding ship breaking industry and following details are the survey based details which we conducted. And with the help of data we clearly draw a precise picture of skill gap analysis in the ship breaking industry Gaddani, Pakistan.

The Figure 5 shows that in our survey we covered $62.4 \%$ of manufacturing sector, $18.3 \%$ of ship breaking industry which is quite enough for our study. And on the basis of these $18.3 \%$ we are figuring out the demand of this sector.

As here our main purpose is to work on ship breaking sector and according to the survey we collected different information regarding existing skill work force. So according to the Table 2 there is no TEVT graduates which are working in this sector, 43 percent work based learners are engaged in this sector, 57 percent workers are engaged from informal sector and there are no workers from other sector. It is clear from this table that this sector needs improvement as there is requirement of TEVT Graduates just to reduce the hazards.

This Table 3 is much precise as it clearly explains that how many degrees, di- 


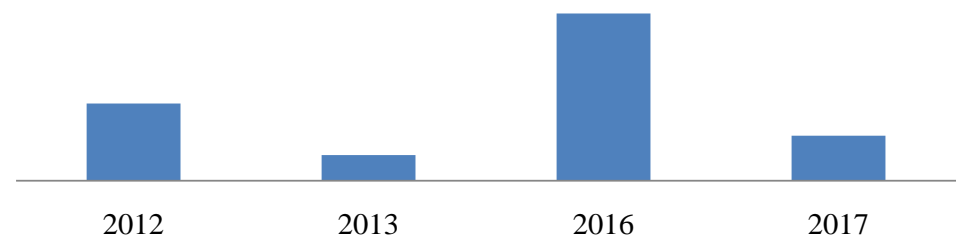

Figure 4. Deaths in Ship Breaking Industry Pakistan (2012-17).

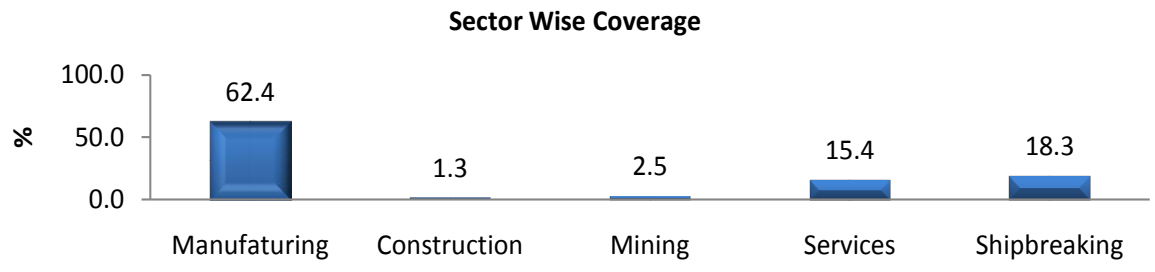

Figure 5. Sector wise coverage.

Table 2. Source of exiting skilled workforce.

\begin{tabular}{ccccccc}
\hline Sector & Manufacturing & Construction & Mining & Services & Shipbreaking & Total \\
\hline TVET Graduate & 15.0 & 9.1 & 11.6 & 7.9 & 0.0 & 12.1 \\
Work based learner & 34.0 & 9.1 & 51.2 & 51.5 & 43.0 & 37.3 \\
Informal Sector & 50.6 & 40.9 & 37.2 & 38.0 & 57.0 & 49.3 \\
Others & 0.5 & 40.9 & 0.0 & 2.6 & 0.0 & 1.2 \\
\hline
\end{tabular}

Table 3. Level and Sector wise existing skilled workforce.

\begin{tabular}{|c|c|c|c|c|c|c|c|}
\hline Sector & Degree & B. Tech & DAE & Short course & Certificate & Diploma & Others \\
\hline Manufacturing & 9 & 12 & 8 & 38 & 29 & 3 & 1 \\
\hline Construction & 0 & 0 & 33 & 67 & 0 & 0 & 0 \\
\hline Mining & 0 & 13 & 13 & 63 & 13 & 0 & 0 \\
\hline Services & 3 & 0 & 0 & 56 & 26 & 15 & 0 \\
\hline Shipbreaking & 12 & 0 & 5 & 5 & 2 & 4 & 72 \\
\hline
\end{tabular}

ploma and certificates holders are working in this sector. So throwing light on ship breaking sector we see clearly from the table that $72 \%$ of the work force are those who have no degree, diploma and certificates. $12 \%$ of the work force are degree holders, $5 \%$ are DAE graduates, $5 \%$ of the work force are holding short course, $4 \%$ of the work force are holding diploma's and $2 \%$ of the existing work force are holding certificates. These are the basic reasons that why this sector is hazardous and why this sector is not Green.

The Figure 6 clearly mentions the demands of this sector. As there is highest demand of safety incharge as there is no proper trained safety incharge because most the safety measure are taken place in the direction of the incharge and by doing so the possibility of safety is more. Followed by this $21 \%$ Electrician are 
Highest demand Trades in Shipbreaking

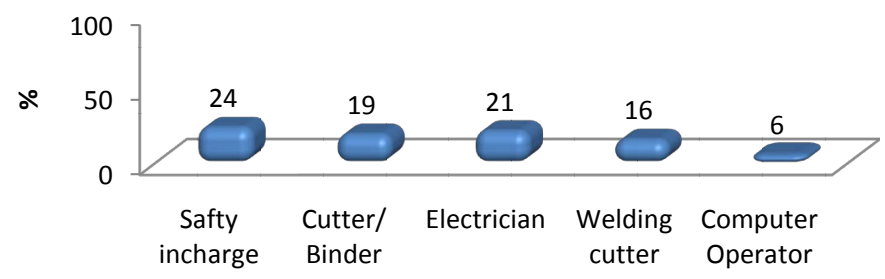

Figure 6. Highest demand trades in shipbreaking.

required, and then this sector requires $19 \%$ skilled cutter/Binder, $16 \%$ welding cutter and 6\% computer operators are the basic requirement of this sector.

According to our survey here in Figure 7 clearly see different skill deficiencies in different sector but if we see precisely the highest skill deficiency is in ship breaking sector which is $75 \%$. And this figure is most shocking that even holding the highest skill deficiency and although this sector is competing in international market. But if the Government of Pakistan give a little importance to this sector and make it green so than we are on that level that we produce steel on bigger level around the world and not even this we will export steel to other countries also. And ultimate impact is on our GDP which is the basic motive of all this.

\subsection{Employer Level of Satisfaction}

This Figure 8 shows the employer level of satisfaction from the TEVT graduates. If we see the graph than we see that the highest satisfaction from the TEVT graduates is in Ship breaking sector which is $83 \%$. So this means that the skill work force should be TEVT graduate in order to make this sector hazardous free and make it Green.

\section{Recommendation/Optimal Solutions}

As we discussed earlier on all the three main issues which are personal protective measures, environmental protective measures, and Incidents which are taking place. All these issues which this sector faces is because of many reasons like no proper safety measures, absence of training, no permanent workers, no hospital facilities nearby, and many more. So these are some basic and important factors that are neglected due to which we can't meet the international standards. These are the basic things which are the reasons of pollution, death of workers, injuries and many diseases associated with it.

To match up the ship breaking sector of developing economies with developed economies there is need of proper machinery, safety dresses, shoes, googles, mask, medical facilities, worker proper training, and their safety. Another thing the ship breaking yard should be shift to the costal side of the beach just for to make it easy the disposal of wastes. And there will be proper medical facilities in case of injuries. And this step is only possible with the collaboration of Government authorities, Private business, and international organization (GIZ, UN etc.). 
Sector Wise Skills Deficiency

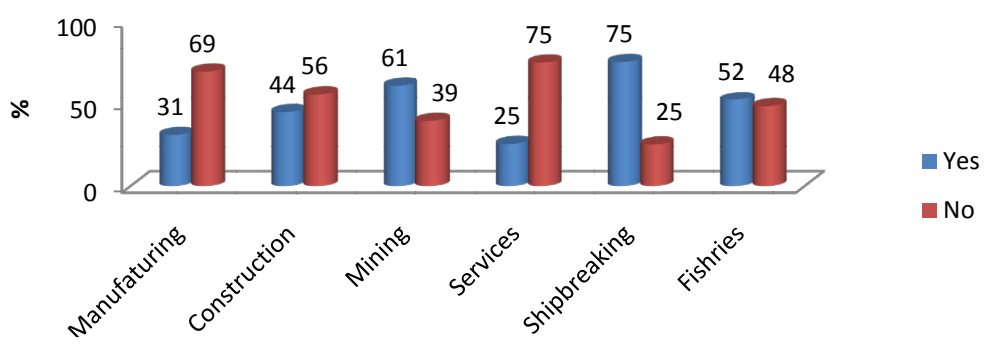

Figure 7. Sector wise skill deficiency.

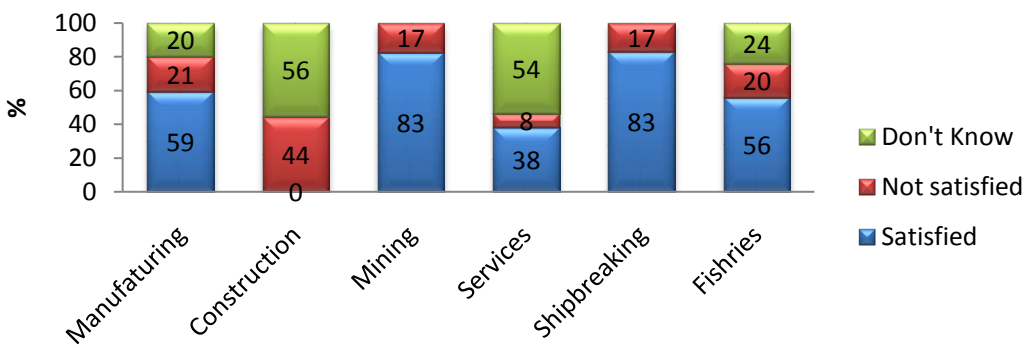

Figure 8. Employer level of satisfaction 1.

The above paragraphs are regarding to safety measures and the current paragraph is about the productive measures. To revive this industry back to his level of 80 's government have to reduces taxes i.e. imports duties and tax on scraps. By doing this sector performance will be better and they can contribute more to GDP. And worker performance can only be speed up only to educate them.

\section{Immediate Applicable}

This is also a kind of solution which will be immediately applicable. As government can do anything like for the orange train project the government of Pakis$\tan$ free the custom duties on the machinery, equipment's which are used in this project. So like orange train project if government also focuses on this project and also release custom duties on the modern machinery used in this sector and other advanced safety equipment's. Beside this government should also have to low the tax imposed on this sector. And government should also give subsidy in term of free electricity to this sector.

\section{Medium Term Solution}

Medium term solution means that we have to educate the engaged worker through proper technical and vocational certificates. This can not only handled the injuries which takes place day by day but also the production of this sector defiantly raises. As production rises so automatically the employment opportunity rises and in this way contribution to GDP rises. Another important thing that there are proper medical facilities in case of injuries and a hospital can be built nearby. 


\section{Long Term Solution}

Long term solutions includes that government shows cooperation with entrepreneurs by giving them facilities in term of tax reduction and make this industry the "Green Ship" industry which means hazard free, in all cases personal safety and Environmental Safety [11]. And proper TEVT graduates are provided to minimize the risk regarding all aspects. So these are the only issues and if these issues are handled properly than this will be one of the leading industries which contribution will be much more and more in near future.

\section{Conclusion}

This study focuses the most ignored and the highest imposed taxed sector of Pakistan, which is ship braking sector, this study almost, covers each and every basic needs of this sector due to the ignorance of these basic needs this sector becomes the most hazardous industry of Pakistan. The very first issue is of safety procedures for the engaged work force which is totally neglected as the work force were not properly trained and most of them are from informal sector and on daily wages system. No concept of permanent employees and this is one of the burning reasons due to which injuries and deaths are taking place every next day. Secondly there were no proper medical facilities for the injuries and beside this the workers have no life insurance. Before the era of 1980's this sector was the world's leading industry and after 80 's this sector became the world $3^{\text {rd }}$ dismantling industry just because that high tax rate was imposed and other protective measures. This sector is labeled as the most hazardous sector because there were no proper environmental and life cure policies. All these factors are followed by the main issue as there is no proper education for work force. According to the survey result the skill work force is their basic need as there are no TEVT graduates. If the work force is properly educated through different certificates and diploma than the injuries are death ratios become minimum and the environmental pollution are also be minimized. And ultimately the production increases and the contribution to the GDP also increase which is our ultimate goal.

\section{References}

[1] NGO Ship Breaking Platform (2016) Substandard Ship Breaking: A Global challenge.

[2] Khan, C.K.U. (2014) Pakistan Ship Breaking Industry, Master Mariner.

[3] Iqbal, K.M.J. and Heidegger, P. (2013) The Ship Breaking Outlook: The Way forward for a Green Ship Recycling Industry-Environmental, Health and Safety Condition.

[4] Rana, P.I. (2013) Ship Breaking Slams FBR. https://www.dawn.com/news/799541

[5] Sarraf, Stuer-Lauridsen, M., Dyoulgerov, F., Bloch, M., Wingfield, R. and Roy, S.W. (2010) The Ship Breaking and Recycling Industry in Bangladesh and Pakistan. The World Bank, Washington, DC. 
[6] https://en.wikipedia.org/wiki/Gadani_ship-breaking_yard.

[7] Amin Bhola (2017) Seven Ocean Services. http://www.sos.net.pk/site

[8] Ashraf, Z. and Baloch, Z. (2016) At Least 14 Killed, 59 Injured in Gadani Shipbreaking Yard Fire. The Express Tribune, Karachi.

[9] ILPI (2016) Shipbreaking Practices in Bangladesh, India and Pakistan: An Investor Perspective on the Human Rights and Environmental Impacts of Beaching. International Law and Policy Institute, Oslo.

[10] Human Rights Commission of Pakistan (2017) Another Accidental Death Reported at Gadani Ship-Breaking Yard, 2017. Human Rights Commission of Pakistan, Karachi.

[11] Rousmaniere, P. and Raj, N. (2007) Shipbreaking in the Developing World: Problems and Prospects. International Journal of Occupational and Environmental Health, 13, 359-368. https://doi.org/10.1179/oeh.2007.13.4.359 